\title{
KEPADATAN TULANG, AKTIVITAS FISIK DAN KONSUMSI MAKANAN BERHUBUNGAN DENGAN KEJADIAN STUNTING PADA ANAK USIA 6 - 12 TAHUN
}

\author{
Heryudarini Harahap ${ }^{12}$, Sandjaja ${ }^{13}$, Moesijanti Soekatri ${ }^{14}$ \\ ${ }^{1}$ Tim SEANUTS, Persatuan Ahli Gizi Indonesia (PERSAGI) \\ 2Badan Penelitian dan Pengembangan Daerah Provinsi Riau \\ ${ }^{3}$ Pusat Teknologi Terapan Kesehatan dan Epidemiologi Klinik \\ ${ }^{4}$ Jurusan Gizi, Poltekkes Kemenkes Jakarta II, Jakarta
}

\section{ABSTRAK}

Studi ini bertujuan untuk menganalisis hubungan antara kepadatan tulang, aktivitas fisik, dan konsumsi makanan dengan kejadian stunting. Analisis menggunakan data anak usia 6.0 - 12.9 tahun $(\mathrm{n}=192)$ dari South East Asian Nutrition Survey (SEANUTS) tahun 2011.Kepadatan tulang diukur dengan metoda dual energy X-ray absorptiometry (DXA), yang dikategorikan menjadi rendah ( $\leq-2 \mathrm{SD}$ ) dan normal (> $2 \mathrm{SD}$ ). Aktivitas fisik dikumpulkan dengan menggunakan pedometer. Aktivitas fisik yang dikategorikan menjadi rendah $(<11,636$ untuk laki-laki dan $<10,311$ langkah untuk perempuan), sedang $(11,636-15,891$ langkah untuk laki-laki dan 10,311 - 14,070 langkah untuk perempuan) dan tinggi ( $>15,891$ langkah untuk laki-laki dan $>14,070$ langkah untuk perempuan). Konsumsi makanan dikumpulkan dengan cara 24 hours dietary recall. Konsumsi protein dikategorikan menjadi rendah ( $<80 \% \mathrm{RDA})$ dan normal $(\geq 80 \% \mathrm{RDA})$. Logistic regression analysis digunakan untuk melihat hubungan antara variabel dependen dan independen. Hasil studi menunjukkan anak dengan kepadatan tulang rendah berisiko untuk menjadi stunting 5,3 kali (OR = $5,325 ; \mathrm{Cl}=1,075-26,387)$ dibandingkan dengan anak kepadatan tulang normal. Aktivitas fisik anak sedang $(O R=0,139 ; \mathrm{Cl}=0,037-0,521)$ merupakan faktor protektif untuk kejadian stunting dibandingkan dengan aktivitas tinggi. Anak dengan konsumsi protein $<80 \%$ dari angka kecukupan gizi (AKG) yang dianjurkan berisiko untuk menjadi stunting 6,4 kali $(\mathrm{OR}=6,448 ; \mathrm{Cl}=1,756-23,672)$ dibandingkan anak dengan konsumsi protein $\geq 80 \%$. Selain akibat kekurangan konsumsi protein, perhatian juga perlu diberikan kepada aktivitas fisik dan kepadatan tulang anak untuk mencegah stunting dan akibat jangka panjangnya.

Kata kunci: stunting, kepadatan tulang, aktivitas fisik

\section{ABSTRACT}

\section{BONE MINERAL DENSITY, PHYSICAL ACTIVITY, AND DIETARY INTAKES ARE ASSOCIATED WITH STUNTING IN 6-12 YEARS OLD CHILDREN}

This study assessed the association of stunting in schoolage children (6-12 year old) with bone mineral density (BMD), physical activity (PA), and dietary intakes. Data on 6-12 year old children $(n=192)$ from the South East Asian Nutrition Survey (SEANUTS) 2011. BMD was measured using DXA, which was categorized into low ( $\leq-2$ SD) and normal ( $>-2$ SD). Physical activity (PA) was measured using pedometers. PA was categorized into low ( $<11,636$ steps for boys and $<10,311$ steps for girls), moderate $(11,636-15,891$ steps for boys and 10,311 - 14,070 steps for girls) and high (>15,891 steps for boys and 14,070 steps for girls). Dietary data was collected by 24 hours dietary recall. Protein consumption is categorized into low $(<80 \% \mathrm{RDA})$ and normal ( $\geq 80 \% \mathrm{RDA})$. Logistic regression analysis was used to test the association. The results showed that children with low bone density $(\leq-2 \mathrm{SD})$ had a 5.3 times higher risk to be stunted (OR $=5.325 ; 95 \% \mathrm{Cl}=1.075$ to 26.387 ) than children with normal bone density. Moderate physicial activity was a protective factor for stunting ( $\mathrm{OR}=0.139 ; 95 \% \mathrm{Cl}=0.037$ to 0.521 ) than children with high physical activity. Children who consumed $<80 \%$ of RDA of protein had a higher risk of being stunted ( $\mathrm{OR}=6.448 ; 95 \% \mathrm{Cl}=1.756$ to 23.672 ) than children with protein intake $\geq 80 \%$. Therefore, next to improving protein intake, attention also is given to physical activity and bone mineral density to prevent stunting and its long-term impact.

Keywords: stunting, bone mineral density, physical activity 


\section{PENDAHULUAN}

S tunting adalah jika tinggi badan menurut umur berada di bawah -2 SD World Health Organization standard. ${ }^{1}$ Stunting merupakan salah satu masalah gizi pada anak usia sekolah di Indonesia dengan prevalensi yaitu 30,7 persen pada tahun $2013^{2}$. Prevalensi stunting tahun 2013 menurun dibandingkan dengan tahun 2010 yaitu 35,6 persen ${ }^{3}$, namun angka tersebut dikategorikan tinggi dan merupakan masalah kesehatan masyarakat karena angka stunting masih di atas 30 persen. ${ }^{1}$

Stunting berhubungan dengan perkembangan yang buruk pada balita dan berakibat pada berkurangnya pengetahuan dan serta prestasi sekolah. Stunting dapat mengakibatkan terganggunya fungsi kognitif, terganggunya proses metabolisme, dan terjadinya penurunan produktivitas. ${ }^{4}$ Stunting disebutkan juga merupakan faktor risiko untuk berkurangnya kelangsungan hidup, kesehatan masa anak-anak dan dewasa, kapasitas belajar dan produktivitas. ${ }^{5}$

Penyebab langsung terjadinya stunting adalah karena intake makanan dan infeksi yang berulang. Stunting merupakan pertumbuhan linier yang gagal untuk mencapai potensi genetik sebagai akibat dari pola makan yang buruk dan penyakit. ${ }^{5}$ Zat gizi utama yang berhubungan dengan kejadian stunting adalah protein. Hal ini terjadi apabila kekurangan protein secara terus menerus dapat menyebabkan pertumbuhan anak balita terhambat dan tidak sesuai dengan umurnya. Hasil penelitian terdahulu menunjukkan bahwa ada hubungan antara konsumsi protein dengan stunting, anak-anak dengan konsumsi protein yang rendah berisiko untuk menjadi stunting dibanding anak-anak dengan konsumsi protein baik. ${ }^{6,7}$

Anak-anak yang stunting biasanya pada saat dewasa juga menjadi orang dewasa yang stunting. Anak-anak stunting sering mengalami keterlambatan dalam kematangan tulang. Hasil penelitian yang dilakukan oleh Ibrahim et.al menunjukkan bahwa remaja stunting mempunyai kepadatan tulang yang rendah, dan orang dewasa stunting lebih banyak yang terkena osteoporosis. ${ }^{8}$

Penelitian terdahulu menunjukkan bahwa anak-anak stunting lebih banyak menghabiskan waktu dengan jenis aktivitas fisik yang mengeluarkan energi rendah, dan lebih sedikit waktu dengan jenis aktivitas fisik sedang dan tinggi ${ }^{9}$. Penelitian pada remaja perempuan dengan aktivitas fisik yang rendah sampai sedang merupakan faktor protektif terhadap kejadian kurus. Hipotesis yang dikemukakan adalah bahwa penurunan konsumsi energi akan menurunkan aktivitas fisik. ${ }^{10}$

Berbagai studi telah dilakukan tentang stunting tetapi belum banyak studi dalam hubungannya dengan kepadatan tulang dan aktivitas fisik. Analisis ini bertujuan untuk menentukan hubungan antara kepadatan tulang, aktivitas fisik, dan konsumsi makanan dengan kejadian stunting. Pemahaman yang lebih baik tentang faktor-faktor yang terkait dengan stunting dapat membantu dalam mengembangkan intervensi yang relevan atau efektif.

\section{METODE PENELITIAN}

Penelitian South East Asian Nutrition Surveys (SEANUTS) yang dilaksanakan pada tahun 2011 mendapatkan persetujuan etik dari Komisi Etik, Badan Penelitian dan Pengembangan Kesehatan, Kemenkes nomor LB.03.02/KE/6430/2010, persetujuan pelaksanaan penelitian dari Kementerian Dalam Negeri nomor 440.02/1751.D.I serta disetujui oleh the Netherlands Trial Registry nomor NTR2462. Pengumpul data menjelaskan tentang penelitian dan prosedur penelitian pada orangtua atau wali dari anak, jika mereka menyetujui anaknya untuk ikut dalam penelitian maka dimintakan persetujuan setelah penjelasan, jika tidak maka dipilih kembali dari daftar sampel.

SEANUTS adalah survei dengan desain potong lintang (cross-sectional). Lokasi penelitian, jumlah sampel, data yang dikumpulkan dan metoda pengumpulan data disajikan pada paper terdahulu ${ }^{11}$. Analisis ini menggunakan data anak usia 6.0 - 12.9 tahun. Jumlah sampel adalah 192 orang yang berasal dari Kota Jakarta Barat, Kabupaten Sleman, Wonogiri dan Purworejo.

Kepadatan mineral tulang yang diukur dengan cara total body scan menggunakan peralatan dual energy $X$-ray absorptiometry (DEXA) di rumah sakit. Pengukuran dilakukan di RS Cipto Mangunkusumo untuk anak yang berasal dari Jakarta dan di RS Sardjito 
Jogyakarta untuk anak yang berasal dari Sleman, Wonogiri, dan Purworejo. Kepadatan tulang dikategorikan menjadi rendah ( $\leq-2 \mathrm{SD}$ ) dan normal (> 2 SD). ${ }^{12}$

Aktivitas fisik dikumpulkan dengan peralatan pedometer Digi-Walker yang mencatat jumlah langkah. Cara penggunaan pedometer adalah sebagai berikut 1) pedometer di set ke angka 0 dan set hari sebelum dipasang, 2) pedometer dipasang pada ikat pinggang/celana/rok dan diletakkan dikiri atau kanan pinggang, kemudian dipasang tali pada ikat pinggang anak untuk mencegah kehilangan pedometer, 3) pedometer dilepaskan jika melakukan kegiatan yang menyebabkan pedometer menjadi basah, 4) setelah dipasang selama 2 × 24 jam, data jumlah langkah dicatat di dalam kuesioner. Nilai rata-rata dari jumlah langkah yang dihasilkan anak selama dua hari disebut sebagai aktivitas fisik. Aktivitas fisik yang dikategorikan menjadi rendah $(<11,636$ untuk laki-laki dan < 10,311 langkah untuk perempuan), sedang $(11,636-15,891$ langkah untuk laki-laki dan 10,311 - 14,070 langkah untuk perempuan) dan tinggi ( $>15,891$ langkah untuk laki-laki dan > 14,070 langkah untuk perempuan).

Konsumsi makanan ditanyakan dengan metode recall 1×24 jam yang lalu. Enumerator dilengkapi dengan timbangan makanan dan uang untuk membeli makanan jadi setempat untuk memperkirakan dengan tepat berat makanan. Selain itu enumerator juga dibekali food models yang terbuat dari bahan gips untuk memperkirakan lebih tepat berat makanan. Dari wawancara recall $1 \times 24$ jam tersebut dihitung jumlah zat-zat gizi yang dikonsumsi dalam sehari dengan menggunakan software komputer Nutrisoft ${ }^{13}$ yang didasarkan pada nilai gizi dalam Daftar Komposisi Bahan Makanan (DKBM) Indonesia. ${ }^{14}$ Konsumsi energi dikategorikan menjadi rendah ( $<70 \% \mathrm{RDA})$ dan normal $(\geq 70 \%$ RDA). Konsumsi protein dikategorikan menjadi rendah ( $<80 \% \mathrm{RDA})$ dan normal ( $\geq 80 \%$ RDA).

Pengukuran berat badan dilakukan dengan menggunakan timbangan digital AND yang sudah ditera dengan ketelitian $0,1 \mathrm{Kg}$ pada anak dengan pakaian seminimal mungkin. Tim enumerator dibekali dengan celana pendek dan baju ringan bila diperlukan. Pengukuran tinggi badan anak menggunakan microtoise dengan ketelitian $0,1 \mathrm{Cm}$. Pengukuran panjang badan dilakukan dengan kepala menyentuh fiksasi kepala tegak, tungkai kaki tegak lurus. Pengukuran tinggi badan dilakukan tanpa alas kaki dalam posisi tubuh tegak, kepala, punggung, betis, tungkai kaki pantat rapat ke tembok. Dari ukuran antropometri tersebut dihitung nilai z-score tinggi badan menurut umur (TB|U) sesuai dengan WHO Child Growth Standards 200515. Anak dikategorikan menjadi stunting (<-3 SD) dan normal ( $\geq-3 S D)$.

Kuesioner terstruktur digunakan untuk mengumpulkan data sosial ekonomi sampel yang meliputi jenis kelamin, umur, tempat tinggal, pekerjaan orangtua, pendidikan orangtua dan kepemilikan barang berharga.

Dilakukan weighted (pembobotan) dalam analisis data. Analisis data dilakukan secara univariabel dan multivariabel regresi logistik. Variabel yang dimasukkan dalam analisis multivariat adalah variabel dengan $p$ value $<0,25^{16}$. Sebagai variabel terikat adalah status gizi (stunting dan normal) dan variabel bebas adalah kepadatan tulang, aktivitas fisik, konsumsi protein, konsumsi energi, perbedaan biologis (jenis kelamin) dan tempat tinggal. Selanjutnya dilakukan analisis interaksi pada variabel independen yang bermakna yang diduga berhubungan.

\section{HASIL}

Pada Tabel 1 disajikan karakteristik sampel penelitian. Jumlah anak laki-laki lebih besar dibanding anak perempuan. Sebagian besar anak termasuk dalam kelompok umur 6,0 - 8,9 tahun dan bertempat tinggal di daerah perkotaan. Lebih dari 60 persen ibu dari anak berpendidikan SMA ke bawah, hampir 70 persen dengan pekerjaan ayah tidak tetap dan lebih dari 50 persen berada pada tingkat pendapatan kuintil III ke bawah. Dapat dikatakan bahwa sampel dari penelitian ini sebagian besar berasal dari sosial ekonomi menengah ke bawah (Tabel 1).

Pada Tabel 2 disajikan analisis bivariabel faktor risiko yang berhubungan dengan kejadian stunting. Kepadatan tulang, aktivitas fisik, konsumsi protein, dan tempat tinggal berhubungan dengan kejadian stunting. Anak yang mempunyai kepadatan tulang rendah berisiko 2,8 kali untuk menjadi stunting dibandingkan anak dengan kepadatan tulang baik $(\mathrm{OR}=2,805 ; \quad 95 \% \mathrm{Cl}: \quad 1,448-5,435)$. 
Aktivitas fisik sedang $(\mathrm{OR}=0,215 ; 95 \% \mathrm{Cl}$ : 0,069-0,667). memberikan efek protektif terhadap kejadian stunting dibandingkan dengan aktivitas fisik tinggi. Anak dengan konsumsi protein $<80 \%$ RDA berisiko untuk menjadi stunting dibanding anak dengan konsumsi protein $\geq 80 \%$ RDA (OR=2,000; $95 \% \mathrm{Cl}: 0,753-5,309)$. Anak yang tinggal di desa berisiko 3,5 untuk menjadi stunting dibandingkan dengan anak yang tinggal di kota (OR=3,453; 95\% Cl : 1,240-9,615).

Variabel-variabel dengan nilai $p<0,25$ dimasukkan dalam analisis multivariabel yaitu kepadatan tulang, aktivitas fisik, konsumsi protein, jenis kelamin dan tempat tinggal. Model akhir analisis multivariabel yang berhubungan dengan kejadian stunting disajikan pada Tabel 3. Anak dengan kepadatan tulang rendah berisiko 5,3 kali untuk menjadi stunting dibanding anak dengan kepadatan tulang normal (OR=5,325; 95\% Cl:1,075-26,387), anak dengan aktivitas fisik sedang mempunyai efek protektif terhadap kejadian stunting dibanding anak dengan aktivitas fisik tinggi $(O R=0,139$; $95 \% \mathrm{Cl}: 0,037-0,521)$, dan anak dengan konsumsi protein rendah berisiko 6,5 kali untuk menjadi stunting dibanding anak dengan konsumsi protein tinggi (OR=6,448; $95 \% \mathrm{Cl}: 1,756-23,672)$. Tidak ditemukan interaksi $(p>0,05)$ antara konsumsi protein dengan kepadatan tulang, konsumsi protein dengan aktivitas fisik dan kepadatan tulang dengan aktivitas fisik dengan kejadian stunting.

Nagelkerke R Square menunjukkan bahwa variabel independen terhadap kejadian stunting sebesar 0,472 yang berarti variabel independen (kepadatan tulang, aktivitas fisik, dan konsumsi protein) dapat menyebabkan kejadian stunting $47,2 \%$ sisanya disebabkan oleh variabel lain (Tabel 3).

Tabel 1

Karakteristik Sampel

\begin{tabular}{lrc}
\hline Variabel & $\mathrm{n}(192)$ & $\%$ \\
\hline Gender & 112 & 58,6 \\
Laki-laki & 80 & 41,4 \\
Perempuan & & \\
Umur (tahun) & 118 & 61,6 \\
$6.0-8.9$ & 74 & 38,4 \\
$9.0-12.9$ & & \\
Tempat tinggal & 160 & 83,4 \\
Kota & 32 & 16,6 \\
Desa & & \\
Pekerjaan Ayah* & 58 & 30,5 \\
Pekerjaan tetap & 127 & 68,5 \\
Pekerjaan tidak tetap & & \\
Pendidikan ibu & 72 & 37,4 \\
- SMA ke atas & 120 & 62,6 \\
- SMP ke bawah & & \\
Tingkat pendapatan & 21 & 11,3 \\
Kuintil I & 27 & 14,0 \\
Kuintil II & 54 & 28,4 \\
Kuintil III & 51 & 26,3 \\
Kuintil IV & 39 & 20,0 \\
Kuintil V & &
\end{tabular}

*Terdapat missing value 7 orang karena tidak mempunyai ayah 


\section{BAHASAN}

Stunting merupakan faktor risiko untuk berkurangnya kelangsungan hidup, kesehatan masa anak-anak dan dewasa, kapasitas belajar dan produktivitas. Proses terjadinya stunting umumnya disebabkan oleh intake makanan dan infeksi yang berulang ${ }^{5}$. Masalah stunting menunjukkan ketidakcukupan gizi dalam jangka waktu panjang yaitu kurang energi dan protein serta beberapa zat mikro lainnya.
Hasil penelitian ini menunjukkan bahwa sekitar 35 persen anak mengkonsumsi $<80$ persen angka kecukupan gizi protein. Kekurangan protein akan menyebabkan terjadinya gangguan pertumbuhan pada anak. Anak dengan konsumsi protein $<80$ persen berisiko 6,5 kali untuk menjadi stunting dibanding anak dengan konsumsi protein $\geq 80$ persen. Penelitian ini sejalan dengan penelitian yang dilakukan oleh Gibson, et.al. ${ }^{6}$ and Esfarjani, et.al. ${ }^{7}$

Tabel 2

Analisis Univariabel Faktor-Faktor yang Berhubungan dengan Risiko Kejadian Stunting

\begin{tabular}{|c|c|c|c|c|c|c|c|}
\hline \multirow{3}{*}{$\begin{array}{l}\text { Variabel Independen } \\
\text { dan Kategori }\end{array}$} & \multicolumn{5}{|c|}{ Faktor risiko kejadian stunting } & \multirow{3}{*}{$\mathrm{p}$} & \multirow{3}{*}{$\begin{array}{c}\text { OR } \\
(95 \% \mathrm{Cl})\end{array}$} \\
\hline & \multirow[b]{2}{*}{$\mathrm{n}$} & \multicolumn{2}{|c|}{ Normal } & \multicolumn{2}{|c|}{ Stunting } & & \\
\hline & & $\mathrm{n}$ & $\%$ & $\mathrm{n}$ & $\%$ & & \\
\hline \multicolumn{8}{|l|}{ Kepadatan tulang } \\
\hline Baik & 154 & 140 & 90,9 & 14 & 9,1 & \multirow[t]{2}{*}{0,002} & \multirow[t]{2}{*}{$2,805(1,448-5,435)$} \\
\hline Rendah & 38 & 34 & 89,5 & 4 & 10,5 & & \\
\hline \multicolumn{8}{|l|}{ Aktivitas fisik } \\
\hline Tinggi & 19 & 11 & 57,9 & 8 & 42,1 & & \multirow{3}{*}{$\begin{array}{c}0,215(0,069-0,667) \\
-\end{array}$} \\
\hline Sedang & 71 & 61 & 85,9 & 10 & 14,1 & 0,008 & \\
\hline Rendah & 102 & 102 & 100,0 & 0 & 0,0 & 0,996 & \\
\hline \multicolumn{8}{|l|}{ Konsumsi protein } \\
\hline$\geq 80 \%$ & 125 & 116 & 92,8 & 9 & 7,2 & \multirow{2}{*}{0,158} & \multirow{2}{*}{$2,000(0,753-5,309)$} \\
\hline$<80 \%$ & 67 & 58 & 86,6 & 9 & 13,4 & & \\
\hline \multicolumn{8}{|l|}{ Konsumsi energi } \\
\hline$\geq 70 \%$ & 70 & 65 & 92,9 & 5 & 7,1 & \multirow{2}{*}{0,333} & \multirow{2}{*}{$1,685(0,580-4,896)$} \\
\hline$<70 \%$ & 122 & 108 & 88,5 & 14 & 11,5 & & \\
\hline \multicolumn{8}{|l|}{ Gender } \\
\hline Laki-laki & 112 & 105 & 93,8 & 7 & 6,3 & \multirow[t]{2}{*}{0,079} & \multirow[t]{2}{*}{$2,391(0,884-6,489)$} \\
\hline Perempuan & 80 & 69 & 86,3 & 11 & 13,8 & & \\
\hline \multicolumn{8}{|l|}{ Umur } \\
\hline $6.0-8.9$ & 118 & 109 & 92,4 & 9 & 7,6 & \multirow[t]{2}{*}{0,28} & \multirow[t]{2}{*}{$1,703(0,643-4,511)$} \\
\hline $9.0-12.9$ & 74 & 65 & 87,7 & 9 & 12,3 & & \\
\hline \multicolumn{8}{|l|}{ Tempat tinggal } \\
\hline Kota & 160 & 148 & 92,5 & 12 & 7,5 & \multirow{2}{*}{0,013} & \multirow{2}{*}{$3,453(1,240-9,615)$} \\
\hline Desa & 32 & 25 & 78,1 & 7 & 21,9 & & \\
\hline Pekerjaan Ayah & & & & & & & \\
\hline Pekerjaan tetap & 58 & 54 & 93,1 & 4 & 6,9 & & \\
\hline Pekerjaan tidak tetap & 127 & 113 & 89,0 & 14 & 11,0 & 0,380 & $1,6 / 3(0,526-5,322)$ \\
\hline Pendidikan ibu & & & & & & & \\
\hline SMA keatas & 72 & 67 & 93,1 & 5 & 6,9 & & \\
\hline SMP kebawah & 120 & 107 & 89,1 & 13 & 10,9 & 0,362 & $1,643(0,560-4,819)$ \\
\hline Tingkat pendapatan & & & & & & & \\
\hline Kuintil I & 21 & 20 & 95,2 & 1 & 4,8 & & \\
\hline Kuintil II & 27 & 22 & 81,5 & 5 & 18,5 & 0,301 & $2,788(0,400-19,429)$ \\
\hline Kuintil III & 54 & 48 & 88,9 & 6 & 11,1 & 0,615 & $1,617(0,249-10,511)$ \\
\hline Kuintil IV & 51 & 46 & 90,2 & 5 & 9,8 & 0,756 & $1,356(0,199-9,236)$ \\
\hline Kuintil V & 39 & 37 & 94,9 & 2 & 5,1 & 0,635 & $0,572(0,057-5,750)$ \\
\hline
\end{tabular}


Tabel 3

Analisis Multivariabel Faktor-Faktor yang Berhubungan dengan Kejadian Stunting

\begin{tabular}{|c|c|c|c|c|}
\hline \multirow{2}{*}{ Variabel } & \multirow{2}{*}{$p$} & \multirow{2}{*}{ OR } & \multicolumn{2}{|c|}{ 95\% C.I.for EXP(B) } \\
\hline & & & Lower & Upper \\
\hline \multicolumn{5}{|l|}{ Kepadatan tulang } \\
\hline \multicolumn{4}{|l|}{ Normal } & 26,387 \\
\hline \multicolumn{5}{|l|}{ Aktivitas fisik } \\
\hline \multicolumn{5}{|l|}{ Tinggi } \\
\hline Sedang & 0,003 & 0,139 & 0,037 & 0,521 \\
\hline Rendah & 0,995 & 0,000 & - & -. \\
\hline \multicolumn{5}{|l|}{ Konsumsi protein } \\
\hline \multicolumn{5}{|l|}{ Baik } \\
\hline Kurang & 0,005 & 6,448 & 1,756 & 23,672 \\
\hline Constant & 0,101 & 0,404 & & \\
\hline
\end{tabular}

Omnibus Test $=<0,001$

1. STEP

MUSCLE MASS ADEQUATE FOR BODY HEIGHT?

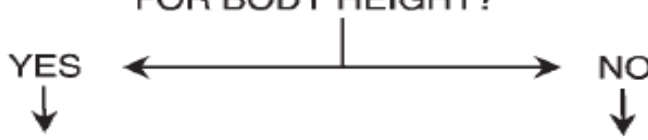

2. STEP

BMC ADEQUATE FOR MUSCLE MASS?
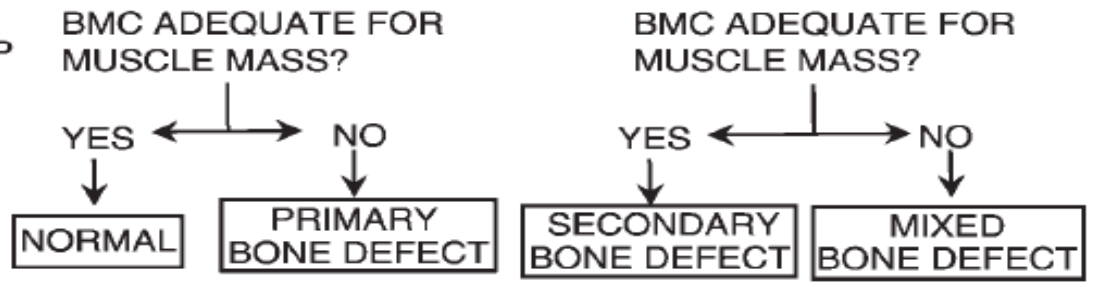

Gambar 1

Diagnostik algoritma untuk kejadian osteoporosis (Schoenau E et al.. ${ }^{17}$

Protein diperlukan untuk pembentukan tulang dan otot pada anak-anak yang sedang dalam masa pertumbuhan. Selain itu protein juga berfungsi sebagai 1) sumber energi dan sebagai cadangan makanan, 2) pembentukan dan perbaikan sel dan jaringan, 3) pengatur keseimbangan kadar asam basa dalam sel, 4) sintesis hormon, enzim, dan antibodi, 4) menjaga kekebalan tubuh, sehingga kekurangan protein pada masa pertumbuhan akan menyebabkan terjadinya stunting.

Pada dekade terakhir terjadi perhatian yang besar dalam penilaian kepadatan tulang pada anak-anak. Hal ini karena adanya fakta bahwa risiko osteoporosis pada orang dewasa dipengaruhi oleh puncak massa tulang, yang sebagian besar dicapai selama masa kanakkanak dan remaja.

Pada Gambar 1, disajikan diagnostik algoritma untuk kejadian osteoporosis. Kondisi pertama adalah massa otot sesuai dengan tinggi badan, selanjutnya jika kandungan mineral tulang sesuai untuk massa otot maka tulang dikatakan 'normal', tetapi jika kandungan mineral tulang lebih rendah dari yang diharapkan untuk massa otot maka situasi ini didiagnosis sebagai 'cacat tulang primer'. Pada kondisi kedua adalah massa otot tidak sesuai dengan tinggi badan, selanjutnya walaupun kandungan mineral tulang memadai namun massa namun kekuatannya terlalu rendah untuk tinggi badan dan dikatakah sebagai 'cacat 
tulang sekunder', jika kandungan tulang rendah dikatakan 'cacat tulang campuran'. Konsep sederhana adalah analisis massa tulang harus difokuskan pada fungsi tulang. Fungsi utama tulang adalah untuk menyediakan kekuatan yang cukup (tidak hanya massa tulang yang cukup) untuk menjaga dari terjadinya patah tulang spontan. ${ }^{17}$

Hasil penelitian ini menemukan bahwa anak dengan kepadatan tulang rendah berisiko 5,3 kali untuk menjadi stunting dibanding anak dengan kepadatan tulang normal. Mineralisasi tulang adalah tahap perkembangan penting yang perlu dicapai pada masa anak-anak dan remaja. Akumulasi massa tulang umumnya sejajar dengan pertumbuhan linear, sehingga persentase pembentukan massa tulang yang besar dicapai selama masa pertumbuhan cepat (growth spurt). Kegagalan untuk mencapai massa tulang yang memadai selama masa remaja merupakan faktor risiko untuk osteoporosis. $^{8} \quad$ Penelitian terdahulu mengungkapkan bahwa remaja stunting mempunyai kepadatan tulang yang rendah, dan orang dewasa stunting lebih banyak yang terkena osteoporosis. ${ }^{10}$ Zat gizi makro yang berhubungan dengan pembentukan tulang adalah protein, sedangkan zat gizi mikro adalah kalsium, phospor dan zink. Pada analisis ini hanya zat gizi protein yang berhubungan bermakna dengan stunting, namun tidak ditemukan ada interaksi antara protein dengan kepadatan tulang pada kejadian stunting.

Penelitian terdahulu yang dilakukan di Bangladesh $^{10}$ menemukan bahwa remaja perempuan dengan aktivitas fisik yang rendah sampai sedang merupakan faktor protektif terhadap kejadian kurus $(\mathrm{OR}=0,43 ; 95 \% \mathrm{Cl}$ : 0,22 - 0,82). Hasil penelitian ini menunjukkan bahwa anak dengan aktivitas fisik sedang merupakan faktor protektif $(\mathrm{OR}=6,448$; $95 \% \mathrm{Cl}: 1,756-23,672)$ untuk kejadian stunting dibanding anak dengan aktivitas fisik tinggi. Keseimbangan antara energi yang dikonsumsi dan energi yang dikeluarkan merupakan faktor risiko kejadian stunting pada anak dengan aktivitas fisik rendah dan tinggi. Anak-anak dengan konsumsi yang rendah diasumsikan tidak mempunyai aktivitas yang banyak karena mereka tidak mempunyai energi yang cukup untuk beraktivitas. Anak-anak dengan aktivitas yang tinggi akan mengeluarkan banyak energi, jika konsumsi energi tidak mencukupi maka akan dilakukan pemecahan protein untuk memenuhi kebutuhan energi. Penelitian yang dilakukan oleh Chahal et.al.18 menunjukkan bahwa aktivitas fisik dengan intensitas tinggi pada wanita paruh baya berhubungan dengan kepadatan tulang. Pada penelitian ini tidak ditemukan interaksi antara aktivitas fisik dan kepadatan tulang dengan risiko kejadian stunting, hal ini diduga karena proses pertumbuhan tulang pada anak masih berlangsung berbeda dengan orang tua yang mengalami penurunan kepadatan tulang sehingga memerlukan aktivitas fisik dengan intensitas tinggi untuk mencegah terjadinya osteoporosis.

Implikasi dari temuan ini menegaskan kembali bahwa protein penting untuk pertumbuhan anak. Adanya keseimbangan antara aktivitas fisik dan konsumsi energi Aktivitas fisik yang cukup dan sesuai diperlukan selama masa pertumbuhan anak. Kepadatan tulang pada masa pertumbuhan berhubungan dengan kejadian stunting.

\section{SIMPULAN DAN SARAN}

\section{Simpulan}

Kejadian stunting berhubungan signifikan dengan kepadatan tulang, aktivitas fisik dan konsumsi protein pada anak usia sekolah. Anak dengan kepadatan tulang rendah berisiko untuk menjadi stunting 5,3 kali $(\mathrm{OR}=5,325 ; 95 \% \mathrm{Cl}=$ 1,075 - 26,387) dibandingkan dengan anak dengan kepadatan tulang normal, dan aktivitas fisik sedang $(\mathrm{OR}=0,139 ; 95 \% \mathrm{Cl}=0,037-$ 0,521 ) sebagai faktor protektif anak untuk kejadian stunting dibanding anak dengan aktivitas tinggi. Anak dengan konsumsi protein $<80 \%$ dari angka kecukupan gizi (AKG) yang dianjurkan berisiko untuk menjadi stunting 6,4 kali $(\mathrm{OR}=6,448 ; 95 \% \mathrm{Cl}=1,756-23,672)$ dibanding anak dengan konsumsi protein $\geq 80 \%$.

\section{Saran}

Selain akibat kekurangan konsumsi zat gizi terutama protein, perhatian juga perlu diberikan kepada aktivitas fisik dan kepadatan tulang anak untuk mencegah stunting dan akibat jangka panjangnya. Diperlukan penelitian lebih lanjut tentang bagaimana interaksi aktivitas fisik kepadatan tulang dan konsumsi protein dalam kejadian stunting. Studi longitudinal diperlukan 
untuk memahami proses berkurangnya kepadatan tulang mulai dari usia muda sampai usia dewasa dengan perawakan pendek.

\section{UCAPAN TERIMA KASIH}

Penulis mengucapkan terima kasih kepada FrieslandCampina/Frisian Flag Indonesia yang telah membiayai penelitian ini dan Parikh Panam serta llse Khouw untuk mereview paper ini.

\section{RUJUKAN}

1. World Health Organization. Nutrition Landscape Information System (NLIS). Country Profile Indicators. Geneva: WHO, 2010.

2. Kementerian Kesehatan. Riset Kesehatan Dasar 2013. Laporan Nasional. Jakarta: Badan Penelitian dan Pengembangan Kesehatan. 2013.

3. Kementerian Kesehatan. Riset Kesehatan Dasar 2010. Laporan Nasional. Jakarta: Badan Penelitian dan Pengembangan Kesehatan., 2011.

4. Dewey KG, Begum K. Long-term consequences of stunting in early life. Maternal and Child Nutrition. 2011: 7 (Suppl. 3):5-18.

5. ACC/SCN and International Food Policy Research Institute (IFPRI). Nutrition Throughout the Life Cycle. 4th Report of The World Nutrition Situation. Geneva: IFRI, 2000.

6. Gibson RS, Manger MS, Krittaphol W, Pongcharoen T, Gowachirapant S, Bailey $\mathrm{KB}$, et al. Does zinc deficiency play a role in stunting among primary school children in NE Thailand?. British Jornal of Nutrition. 2007:97(1):167-175.

7. Esfarjani E, Roustaee $R$, MohammadiNasrabadi F, Esmaillzadeh A. Major Dietary Patterns in Relation to Stunting among Children in Tehran, Iran. J Health Popul Nutr. 2013 Jun;31(2):202-210
8. Ibrahim SA, Samy MA, Matter MK, Saleh AOL. Bone mineral density in Egyptian adolescents and adults with short stature: results of a national survey. Mediterranean Health Journal. 2011;17(8): 687-693.

9. McGregor-Gardner, McGregor-Grantham. Physical activity, undernutrition and child development. Proceeding of the Nutrition Society. 1994;53(1):241-248.

10. Rah JH, Christian P, Shamim AA, Arju AT, Labrique $A B$, et al. Predictors of stunting and thinness in post-menarcheal adolescent girls in rural Bangladesh. Public Health Nutrition. 2009;12(12): 2400 -2409..

11. Sandjaja, Budiman B, Harahap H, Ernawati F, Soekatri MYE, Widodo Y, et al. Desain Penelitian South-East Asia Nutrition Survey (SEANUTS) Di Indonesia. Gizi Indon 2013, 36 (2):75-88

12. ISCD (The International Society for Clinical Densitometry). 2013 ISCD Official Position Pediatric. Available from: http://www.iscd.org/official-positions/2013iscd-official-positions-pediatric/. Diunduh tanggal 4 Agustus 2014.

13. Puslitbang Gizi. Program Nutrisoft Konsumsi Makanan. Bogor, Puslitbang Gizi, 2008.

14. Mahmud MK, Hermana, Zulfianto NA, Apriyantono RR, Hartati B, Simamora T, et al. Tabel Komposisi Pangan Indonesia (TKPI). Jakarta: Elex Media Komputindo, 2008.

15. World Health Organization. Growth Reference Data for 5-19 years. Geneva: WHO, 2007.

16. Lapau B. Metode Penelitian Kesehatan. Jakarta: Yayasan Pustaka Obor, 2012.

17. Schoenau E, Land C, Stabrey A, Remer T, Kroke A. The bone mass concept: problems in short stature. European Journal of Endocrinology, 2004; 151:S8791.

18. Chahal J, Lee R, Luo J. Loading dose of physical activity is related to muscle strength and bone density in middle-aged women. Bone. 2014: 67, 41-45. 